\title{
1. Neoliberalism, precarious work and remaking the geography of global capitalism
}

\section{Andrew Herod and Rob Lambert}

In May 2015 the International Labour Organization (ILO) released its World Employment and Social Outlook: The Changing Nature of Jobs report. Its executive summary was stark in its assessment of the character of work at the beginning of the twenty-first century, detailing the "shift away from the standard employment model, in which workers earn wages and salaries in a dependent employment relationship vis-à-vis their employers, have stable jobs and work full time' (p. 13). As the ILO noted:

In advanced economies, the standard employment model is less and less dominant. In emerging and developing economies, there has been some strengthening of employment contracts and relationships but informal employment continues to be common in many countries and, at the bottom of global supply chains, very short-term contracts and irregular hours are becoming more widespread ... Today, wage and salaried employment accounts for only about half of global employment and covers as few as 20 per cent of workers in regions such as Sub-Saharan Africa and South Asia. In a number of advanced economies, the incidence of wage and salaried employment has been on a downward trend, thus departing from historical patterns. Conversely, own-account work and other forms of employment outside the scope of the traditional employer-employee arrangement are on the rise. In emerging and developing economies, the historical trend towards more wage and salaried employment is slowing down. The incidence of jobs in the informal economy and unpaid family work remain stubbornly high in most developing countries. In addition, within the pool of wage and salaried workers, new dynamics are emerging. Fewer than 40 per cent of wage and salaried workers are employed on a full-time, permanent basis and even that share appears to be declining. This means that over 6 out of 10 wage and salaried workers worldwide are in either part-time or temporary forms of wage and salaried employment. Women are disproportionately represented 
among those in temporary and part-time forms of wage and salaried employment. In short, the standard employment model is less and less representative of today's world of work.

Much of the change highlighted by the ILO has taken place within the context of a discourse and set of policies which laud various market 'freedoms' - 'free trade', the 'freedom' of corporations to engage in mergers and acquisitions without restriction by anti-trust laws, the 'need' for firms to be 'free' of government regulations more generally, and the 'freeing' of various forms of finance capital through the 'deregulation' of markets, amongst others. This discourse has become increasingly dominant in many circles since the 1970s and the adoption by many governments of supply-side economics. A central goal of those arguing for greater market freedoms, though, has been the effort to drive ever greater labour market flexibility, with such flexibility often understood in terms of the 'freedom' of workers to work at a wage they mutually agree upon with an employer rather than one dictated by government edict in the form of minimum wage levels and the 'freedom' of employers to hire and fire workers at will. Going under the name of neoliberalism, the policies developed to implement such 'freedoms' have created an economic and political climate of continuous labour market restructuring, both in terms of labour law change (as with new restrictions on workers' rights to organize and strike) and in terms of the segmentation of the workplace between standard and precarious contracts. ${ }^{1}$ In this regard, the changes in labour market practice since the late 1970s have been far reaching and revolutionary and, for many, herald a return to the conditions experienced by workers under nineteenth-century industrial capitalism. Thus, as one commentator (Elliott 2013) has noted about the rise of so-called 'zero-hour contracts' in Britain, contracts under which workers are guaranteed no work at all and are seen as being almost infinitely flexible in terms of their employers' abilities to hire and fire them:

It is a pity Karl Marx [i]s not around ... The author of the Communist Manifesto would ... have had plenty to say about the news that the official estimates of those working in this form of casualised labour ha[ve] shot up ... $[\mathrm{T}]$ here is a 19th-century feel to zero-hours contracts. It is as though Britain has gone back to the future, returned to an age where the employer had the whip hand and where the rights that workers enjoyed under the feudal system had been removed ... [T] hose on zero-hours contracts earn less than those on staff or on fixed-hours contracts. They have no rights to sick pay. Holiday pay is often refused. And there is plenty of anecdotal evidence to show that if they turn down work when it is offered - even if it is to take a child for a medical appointment - they will be pigeon-holed as not suitably 'flexible'. The choice to refuse work is, in reality, no such thing. These were the sorts of labour 
market practices that gave rise to trade unions in the first place. Back then they had a name: exploitation.

The growth globally of the kinds of precarious work detailed by the ILO and the emergence of what Standing (2011) has called 'the precariat' in recent years, then, have become topics of significant concern to many journalists, academics and policy makers. This is perhaps because the impact on workers' lives of such work, work which is generally low-paid, unstable and lacking in much physical and legal protection, stretches far beyond the workplace. Thus, those who are subjected to it often find that the long and/or unpredictable hours they must work make it difficult to schedule time with friends and family, whilst the low levels of remuneration make it difficult to plan for marriage and children, or for purchasing a home or even for simply living without having to rely upon government assistance or charity. Equally, exposure to dangerous working conditions can result in both short- and long-term health conditions, including stress, cardiovascular disease and contact with various toxins - and, thus, environmentally caused cancers and myriad other bodily ailments. Such health conditions have economic consequences both for the individual worker and his/her family, who may be faced with significant doctors' bills or a shortened working life, and also for the broader society, which must shoulder the cost of healthcare and social payments for these workers or, in countries where such things do not exist, which must address questions of what to do with workers when they are too sick to work. Furthermore, the fact that precarious workers often bounce from employer to employer means that any particular employer has little incentive to train its particular workers, whilst workers themselves have little incentive to go to trade schools to learn skills for a particular type of employment because they know that they are unlikely to find long-term and well-remunerated employment in that industry. Combined, these two phenomena result in a situation in which there is little incentive to increase the overall 'social capital' in any given society. The rise of precarious work, in other words, gives rise to a precarious society, one in which millions of workers end up being caught in a poverty trap.

Given that all of the chapters in this book deal, in various ways, with the issue of precarity, in this introductory chapter we lay out a framework for what follows. The chapter first explores what is meant by 'precarious work' and the degree of its spread in recent years. We then examine some of the reasons for this spread. Finally, we contemplate what this means for workers, especially their ability to counter the new landscapes of work which contemporary neoliberal capitalism is auguring. 


\section{PRECARIOUS WORK: PROBLEMS OF DEFINITION AND THE EXTENT OF THE PHENOMENON}

The term 'precarious work' has become ubiquitous in recent years. As far as we are aware, it was first used by Dorothy Day in 1952 in an article in the Catholic Worker about the French theologian and ex-anarchocommunist Léonce Crenier to describe his embrace of poverty and the apparently salutary effect upon spiritual life of celebrating the condition - precarity - in which the poor live. More recently, it has been adopted by analysts (mostly on the political left) to designate the kinds of low-wage and often dangerous jobs with unpredictable hours and futures with which many workers are increasingly faced. As with many phenomena, though, finding an exact definition of what is meant by the term can prove difficult, for different authors have used it in different ways and other phrases - such as contingent, atypical or non-standard work - have been used to describe more or less the same thing. This is compounded by the fact that the meaning of terms can shift over time. Hence, the expression 'contingent work' was first used in 1985 by Audrey Freedman to describe a management technique whereby workers are hired only when there is an immediate and direct demand for their services and they are laid off when that demand subsides (Freedman 1988). However, within a few years 'contingent work' came to be used to describe a wide variety of types of work, including part-time work, temporary employment, employee leasing, self-employment, contracting out and homebased work (Polivka 1996). Indeed, for some writers pretty much any work that is not a full-time job with a regularly paid wage or salary is considered 'contingent' (and, given the interchangeability for some of 'contingent' and 'precarious' work, could therefore be seen to be 'precarious').

Clearly, though, these types of 'contingent jobs' cover a wide range of workers who may have very different work experiences and socioeconomic statuses but who work in part-time or temporary jobs or who are independent contractors or who work at home for quite dissimilar reasons - janitors who work under these types of conditions because they have no alternative versus 'creative-class' (Florida 2002) workers who are well paid, who largely control the conditions under which they work and who choose when they work and largely for how much they work. Equally, even at the low-wage end of the labour market, these types of jobs are not necessarily transposable. Hence, being part-time does not automatically imply a temporary employment relationship, as many part-time workers work for the same employer for years, even decades, 
whilst many full-time workers flit from employer to employer on a regular basis. Likewise, a home-based lawyer who works for him/herself and a home-based sewer of clothing who is contracted by a major clothes manufacturer are in very different situations, yet both would be considered 'contingent' (and thus, perhaps, 'precarious') under the above definitions. Placing all of these different types of jobs into the same category of 'contingent' and/or 'precarious' work, then, shows the chaotic nature (Sayer 1984) of these concepts.

In similar fashion, the definition of 'standard employment' against which precarious work has frequently been contrasted has also varied over time. Thus, whereas in many Global North economies initially the standard employment norm was based upon an assumption of engagement in blue-collar manufacturing, over time other types of blue-collar work, such as mining and construction, came to be considered part of it. This norm was later extended to white-collar public sector work and also spread from waged employment to corporate salaried work. Furthermore, the kinds of jobs which have typically been considered 'standard' in countries like the US, Canada, Australia and the European nations have themselves only been considered standard for certain types of workers basically, 'a white, heterosexual, able-bodied male worker who, as the primary breadwinner in a household, received decent wages and benefits sufficient to support the family' (Law Commission of Ontario 2009). Within this model, historically 'the norm also assumed a female caregiver who performed the daily upkeep of the household, and who was dependent upon the male breadwinner for income and benefits' (ibid.). 'Standard employment', in other words, was dependent upon unpaid, female domestic labour - labour which, were it done outside the home, might be considered 'precarious'.

As a way to better understand the phenomenon of precarious/ contingent work, Liu and Kolenda $(2011$, p. 6) have developed a matrix which classifies workers along two dimensions: one concerns whether workers are employed in 'contingent industries' or 'traditional industries', whilst the other relates to whether they are hired under 'standard' or 'non-standard' work arrangements (see Table 1.1). Although it may be difficult to distinguish between some workers who might be placed within each of the four boxes which result from these two dimensions (some, for instance, may be well paid and choose to work intermittently, whereas others are poorly paid and forced to work intermittently because of a lack of alternatives, though both could be placed in the 'Nonstandard workers in traditional industries' box), this matrix does provide one way of exploring the nature of precarity. However, given the difficulties of pinning down exactly what is meant by precarious work, 
and given that definitions of standard work are not culturally neutral, it may be the case that the best thing we can do in terms of trying to define what is meant by 'precarious work' is to take a lesson from US Supreme Court Justice Potter Stewart's famous comment about the difficulties of defining legally what is obscene - as he put it, 'I shall not today attempt further to define the kinds of material I understand to be embraced within that shorthand description ['obscene']; and perhaps I could never succeed in intelligibly doing so. But I know it when I see it.' ${ }^{2}$ Certainly, an 'I know precarious work when I see it' approach may be analytically frustrating but it does open the door to a perspective on the issue that is more ethnographic than statistical. Thus, even if workers are in what Liu and Kolenda (2011) define as standard work arrangements in traditional industries, if they feel that their jobs are insecure and precarious this can cause them to behave in ways that workers who do not feel insecure do not, regardless of where they fit on any given matrix.

\section{Table 1.1 Typology of contingent workers}

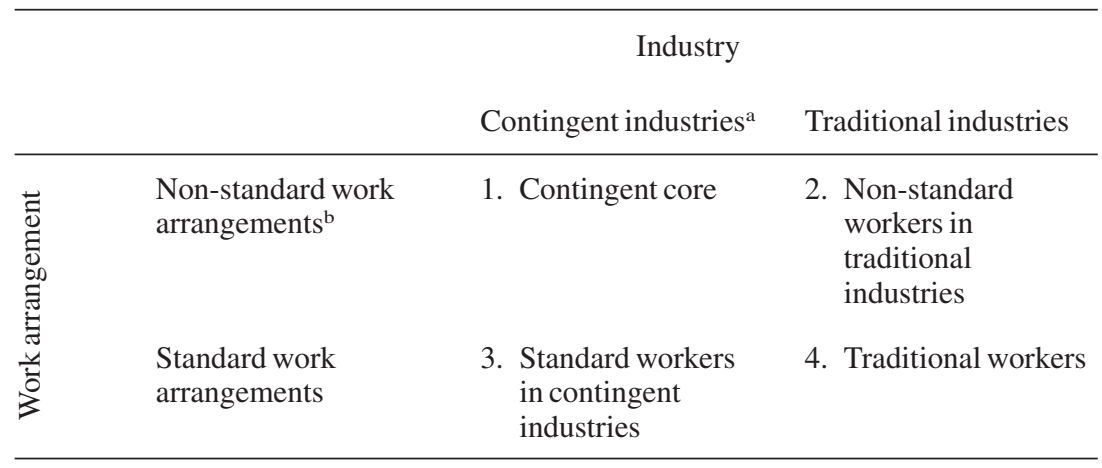

Notes:

${ }^{a}$ Industries with a high likelihood of hiring independent contractors, temporary help workers, day labourers, on-call workers and contract employees.

${ }^{\mathrm{b}}$ Including the self-employed, part-time workers, part-year workers and at-home workers.

Defining what precarious work is, then, is not as easy as it might at first seem. For our part, in general terms - and taking our lead from the ILO (2012, p. 27) - we view precarious work as a means for employers involuntarily

to shift risks and responsibilities on to workers. It is work performed in the formal and informal economy and is characterized by variable levels and degrees of objective (legal status) and subjective (feeling) characteristics of 
uncertainty and insecurity. Although a precarious job can have many faces, it is usually defined by uncertainty as to the duration of employment, multiple possible employers or a disguised or ambiguous employment relationship, a lack of access to social protection and benefits usually associated with employment, low pay, and substantial legal and practical obstacles to joining a trade union and bargaining collectively. ${ }^{3}$

Under such a definition, several types of workers could be considered as experiencing precarious work, including - but not limited to - many independent contractors, temporary help workers, day labourers, on-call workers and employees of contract firms, though not all workers engaged in these kinds of activities should necessarily be viewed as embroiled in precarious work. We believe, then, following the Law Commission of Ontario (2009), that a key element in determining whether any particular worker might be considered to be working in a 'precarious' or 'nonprecarious' job is to move away from an approach which views standard and non-standard employment as categories separate and distinct from one another and towards a multidimensional approach in which employment is viewed on a continuum of being more or less precarious. In so doing, four key dimensions of precarity can be identified: low earnings, a low social wage (including things like poor access to healthcare, pensions and other aspects of a social safety net), little regulatory protection (whether provided by the state or a union contract) and little choice in shaping the kinds of work arrangements in which they find themselves. Considered together, these dimensions produce a much more complex understanding of contemporary developments in labour markets than do simple precarious versus non-precarious, contingent versus noncontingent, typical versus atypical or standard versus non-standard employment binaries.

Having detailed some of the issues with defining what, exactly, is meant by 'precarious work', though, it is the case that during the past few decades the types of 'contingent' work in which precarity can often be exhibited appear to have become more widespread across many economies. Whilst recognizing that statistics can sometimes give misleading counts of precarious work's prevalence - many precarious workers toil in the shadows of the economy, often illegally, and so are often hesitant to be counted in official government statistics, whereas the employers who hire them are often wary of interacting with government officials because they know that many of their employment practices skirt the law and/or may even be overtly illegal - and given the problems of delineating between 'good' and 'bad' temporary and part-time jobs and different types of independently contracted employment, a few figures can help 
give a sense of the scale of the issue. In the USA, for instance, in 2005 some 31 per cent of the labour force worked in what the government termed 'contingent employment', a proportion that had remained fairly constant for the previous decade, even as the total number of such workers grew from 39.6 million in 1995 to 42.6 million in 2005 (US Government Accountability Office 2006a, p. 10). By 2010 this figure had increased to 40.4 per cent (US Government Accountability Office 2015), and many predict that by 2020 about half of all US workers will be contingent. In Japan, as of early 2015 there were 19.9 million 'nonregular' jobs (up from 18.2 million in 2012) and 32.7 million permanent, full-time positions (down from 33.4 million in 2012), meaning that just short of 40 per cent of the labour force was contingent in one way or another (Wall Street Journal 2015). In South Korea 'non-regular' workers make up about one-third of the labour force (McKinsey \& Company 2013, p. 39). In the case of Australia, in 201219 per cent of workers were on some form of casual contract, which provided them with fewer workplace protections than regular workers or those on fixed-term contracts (OECD 2014).

\section{Temporary Work}

Digging a little deeper into the category of 'contingent' work, across the Organisation for Economic Co-operation and Development (OECD) countries the proportion of all paid employment made up by one type of contingent work, that of 'temporary work' (defined by the ILO as work involving fixed-term contracts and agency work), increased from some 9.4 per cent in 1985 to 12 per cent by 2007 (ILO 2012, p. 31). ${ }^{4}$ There is, though, significant variation in this type of employment across the OECD economies. For instance, in the European Union (EU) as a whole the number of temporary jobs during this time period increased by 115 per cent compared to an overall increase in employment of 26 per cent, such that temporary work's share of paid employment increased from 8.3 to 14.7 per cent and temporary work represented some 30 per cent of all paid jobs created during this period. However, there was substantial national disparity - whilst in Spain, Greece and the Netherlands 36.7, 24.6 and 22.9 per cent of all jobs, respectively, were temporary in 2007, in Norway, the United Kingdom, Cyprus and Denmark the numbers were $6.3,8.4,5.8$ and 9.4 per cent. Equally, the reasons for engaging in temporary work varied considerably - in Austria only 8.6 per cent of the 11.5 per cent of the population in temporary work was unable to find a permanent job, whereas in Belgium 74.5 per cent of the 10.7 per cent of 
the workforce in temporary work could not (ILO 2012, p. 31). Nonetheless, as temporary work has increased across the EU so, too, has its involuntariness.

Similar trends have been experienced in Japan and South Korea, which have both seen temporary employment increase. Hence, in the early 1990s 11 per cent of Japanese workers were temporary workers hired directly by companies on short-term contracts and 1 per cent worked for temporary help ('temp') agencies (Houseman and Osawa 1995, p. 10). ${ }^{5}$ By 2012, though, 38.2 per cent were temporary or agency employees (Yamamoto 2013), and the number of Japan's workers who were involuntarily employed in temporary positions had doubled since the late 1990s. For its part, in South Korea by 201432.4 per cent of all workers were temporary (Business Korea 2014). ${ }^{6}$ Such workers typically receive lower wages than their non-temporary counterparts - in 2013 South Korean temporary workers' wages were 64.2 per cent those of full-time workers, although the gap has been closing in recent years. This disparity is at least in part because temporary work is highly gendered - in Japan 52.9 per cent of women but only 17.9 per cent of men in 2012 were temporary or agency employees (Yamamoto 2013), whilst in South Korea in 201554 per cent of temporary workers were women (Business Korea 2014), though this varied by sector (amongst the country's largest companies the proportion was only 22.6 per cent) (DCR Workforce 2014). Meanwhile, in Australia in 201219 per cent of workers were engaged in 'casual employment', although in some sectors the proportion was much higher - around 64 per cent of all hospitality workers were casually employed, as were 43 per cent of workers in the fishing and forestry sectors and 38 per cent of those in retail (OECD 2014, p. 149). Significantly, though, the proportion in casual employment has declined slightly from an average of 20.3 per cent between 1998 to 2007, whilst the proportion of workers who are permanent employees (defined as employees with paid leave entitlements, regardless of the number of hours they work) has increased slightly, from 60.8 per cent in 1998 and 59.6 per cent in 2004 to 63.3 per cent in November 2013 (Australian Industry Group 2014, p. 2). In 2013 about 55 per cent of all casual workers were women and most casual workers were employed in low-skilled service occupations (OECD 2014, p. 149). However, many workers have a fairly low average employment tenure - of all of those employed in November 2013, 43.5 per cent had worked for their present employer for fewer than two years, whilst only 34.8 per cent had worked for more than six years (Australian Bureau of Statistics 2014, p. 16).

In the case of the United States, in 1990 workers in the temporary help services industry (i.e. workers employed by temp agencies, regardless of 
whether their job was actually temporary or not) accounted for about 1.0 per cent of total employment and about 2.0 per cent by 2000 (a jump in numbers from about 1 million to 2.7 million workers), though by 2007 the figure had dropped to about 1.7 per cent (2.3 million workers) (Luo et al. 2010). The significant economic downturn of the late 2000s, however, encouraged more employers to turn to temp agencies for their staffing needs, such that by mid-2014 the proportion of the US labour force employed by a temp agency had grown to 2.1 per cent ( 2.9 million workers) (Staffing Industry Analysts 2014), although there are distinct regional differences - use of temporary workers is much higher in the South and Midwest than in the North-east and West (Luo et al. 2010). Obviously, though, there are many more workers who work temporarily than there are those who are employed by temp agencies. Whilst a paucity of reliable statistics makes it difficult to determine exactly how many workers fall into this category, one surrogate measure that can be used to get a sense of temporary employment is to look at the median length of employment tenure. This shows a significant change in how the US labour market has been working in recent decades. Hence, whereas in 1963 male workers aged 55-64 had a median employment tenure of 14.7 years, those aged $45-54$ a median tenure of 11.4 years, those aged 35-44 a median tenure of 7.6 years and those aged 25-34 a median tenure of 3.5 years, by 2006 the figures were (respectively) only 9.5 years, 8.1 years, 5.1 years and 2.9 years (Copeland 2012, figure 2). Significantly, though, the growing median employment tenure of women and an ageing of the labour force have led to a slight increase in overall median tenure in recent years for workers aged 25 and older, from 5.0 years in 1983 to 5.5 years in 2014 (ibid., figure 1; US Bureau of Labor Statistics 2014, table 1). ${ }^{7}$ Recent increases in the length of median tenure for men are also likely reflective of the stagnant labour market and the fact that people who already had a job were likely to stay with it as they attempted to ride out the economic storm unleashed by the 2008 crisis. Despite the slight increase in length of tenure, though, there is significant evidence that myriad workers are working temporarily when they would prefer full-time jobs - in 2005 (the last year for which Bureau of Labor Statistics figures are available), for instance, 56 per cent of workers hired through temp agencies said they would have preferred to have permanent positions (US Bureau of Labor Statistics 2005, table 11).

\section{Part-time Work}

Other types of work that can be viewed as precarious also play a significant role in the contemporary economy. For instance, across the 
OECD countries in 2011 some 16.5 per cent of workers worked part time, though this varied quite significantly - in the Netherlands as many as 37 per cent of workers were part-timers whilst in Portugal the official number was 11.5 per cent and in Poland it was 8.3 per cent (Fagan et al. 2014, table 2.1). ${ }^{8}$ For the OECD as a whole, the proportion of workers who were part-timers increased by almost 5 percentage points between 2000 and 2011, even as overall employment rates declined owing to the global economic crisis (OECD 2012). In the EU, about 20.4 per cent of workers were part-timers in 2013 (Eurostat 2015), though this varied significantly by gender - in late 2014 overall about 8.7 per cent of men and 32.2 per cent of women held part-time jobs, though the gender division varied significantly by country (in Greece, Portugal and Finland the proportion of men who worked part time was only slightly less than the proportion of women who did so, whereas in Sweden, Belgium, the UK, Austria, Germany and the Netherlands part-time rates were much higher for women than for men) (Economist 2015). In the US, about 14.5 per cent of the labour force worked part time in 1969 (Houseman and Polivka 1998, p. 6), although by 1990 the proportion had increased to approximately 17 per cent and to about 19.5 per cent in 1994 . Although it fell to 16.6 per cent in 2000 and remained around that level for most of the 2000s, once the Global Financial Crisis hit in 2008 levels jumped sharply to over 20 per cent (US Bureau of Labor Statistics 2015a). By February 2015, however, the proportion of workers working part time had declined so that, of the 148 million people employed in the United States, some 27.5 million (18.5 per cent) were employed part time (US Bureau of Labor Statistics 2015b). Of these, 6.6 million (4.5 per cent of all workers) were part-timers because they could not find full-time work, but 20.9 million (13.4 per cent of all workers) worked part time for non-economic reasons, such as because they had to schedule work around various family or personal obligations, because they were pursuing educational or training opportunities, because they were retired or because to work full time would interfere with limits on their earnings owing to their receiving various kinds of social welfare payments (US Bureau of Labor Statistics 2015c).

In Japan, whereas prior to the 1973 oil shock part-time work was rare, by the early 1980s the share of all workers who were part-time had reached 10 per cent. In the 1980s the proportion of the labour force that worked part time increased significantly, from 11 per cent in 1982 to more than 16 per cent in 1992 (Houseman and Osawa 1995, p. 10). In 2007, the Statistics Bureau of the Ministry of Internal Affairs and Communications classified 35.6 per cent of Japan's 53.3 million workers as non-regular employees - 16.6 per cent were 'part-time workers', 7.7 
per cent were 'temporary workers' and 4.2 per cent were 'contract employees' (Asao 2011, p. 4). In May 2014, however, some 29.8 per cent of the labour force worked part time, nearly twice as high as the proportion in the US (Koide 2014, p. 8). Part-time work, though, is highly gendered in Japan - in the first quarter of 201458 per cent of women but only 22 per cent of male workers were part-timers (the equivalent figures in 1984 were about 29 per cent and 8 per cent respectively) (Bloomberg.com 2014).

In South Korea, part-time work has historically been less prevalent than in most other advanced industrial economies but, like other forms of non-standard work, it has grown in recent years as Korean firms have 'required' greater flexibility (Kim and Park 2006, p. 441). ${ }^{9}$ In 2005, for instance, only 7 per cent of workers were employed for fewer than 30 hours a week (Fagan et al. 2014, p. 12). By 2011, however, this figure had jumped to about 13.5 per cent of all workers, though the phenomenon was quite gendered - 18.5 per cent of women but only 10 per cent of men worked part time (ibid., table 2.1) and about 50-60 per cent of all part-time workers were female (ibid., table 2.3). Interestingly, the highest rates of part-time work were seen amongst workers over the age of 65, as many work part time after they retire (ibid., table 2.4). However, in recent years the government has looked to create more part-time jobs, to reduce working hours and to promote widespread flextime as a way to deal with chronic unemployment and to help workers better balance their work-life situation - on average, Korean workers work 420 hours more per year than the OECD norm (Republic of Korea 2014, p. 4). The government is also seeking, though, to convert approximately 65000 non-regular workers in the public sector into regular-status workers and to help nonregular workers in the private sector gain permanent employment status. By requiring companies to introduce guidelines for non-regular workers' employment security the government is simultaneously working to narrow remuneration gaps between regular and non-regular workers. The result is that, out of a labour force of somewhat less than 25 million people in 2012, only about 803000 were involuntary part-time workers (McKinsey \& Company 2013, p. 39).

In China, too, part-time employment seems to be fairly rare, a reflection of the fact that prior to the restructuring of state-owned enterprises most workers held regular full-time jobs - Zhou (2013, p. 361) estimates that in 2006 only about 7.9 per cent of urban workers were part-timers. Under Chinese law, part-timers are supposed to work for an employer for an average of no more than four hours per day and no more than 24 hours per week. They are not required to have a written employment contract and their employer is not required to contribute to 
their social insurance if an employee's total compensation includes the appropriate amount for this and his/her wage is not lower than the local minimum hourly wage (i.e. the worker is expected to take care of his/her own social insurance payments). Part-time workers must be paid at least twice a month and, in some locations, the employer is required either to purchase commercial accident insurance for the worker or pay into the government's work injury insurance programme (Lin 2012). By way of contrast, for their part, at the end of 201331 per cent of Australian workers worked part time (i.e. fewer than 35 hours a week) in their main job (Australian Bureau of Statistics 2014, p. 31). Meanwhile, in nonOECD countries the official level of part-time work varies considerably, from 17.8 per cent in Brazil to 7.7 per cent in South Africa to over 40 per cent in Trinidad and Tobago (Fagan et al. 2014, table 2.1). ${ }^{10}$ The gendered nature of part-time work varies quite a lot across the globe, though. Hence, in the Netherlands, Germany and Belgium more than 80 per cent of part-time workers in 2011 were women, whilst in South Africa, Finland, Poland, Turkey, Chile and Mexico about 60 to 70 per cent were women. In Thailand, Trinidad and Tobago and Indonesia, however, fewer than 50 per cent were women (Fagan et al. 2014, table 2.3). ${ }^{11}$ Looked at slightly differently, in most countries women are more likely to work part time than are men, but this is not always the case - in Trinidad and Tobago, for instance, the official figures indicate that in the early 2000s 22.2 per cent of men were part-timers but only 18.1 per cent of women were (Fagan et al. 2014, table 2.1).

\section{Independent Contracting}

A third type of work that is often seen as potentially precarious and which has become more common is that of 'independent contracting'. In the EU, for instance, between 2000 and 2011 the number of people who were self-employed (both those with and those without employees) increased by 5.6 per cent, whereas the number without employees increased by 12 per cent, such that 15 per cent of the population $(32.8$ million people) were 'independent workers' (Rapelli 2012). However, the growth of independent contractors has varied significantly by field today about 25 per cent of those working in professional, scientific and technical work (about 2.7 million workers) and 22 per cent of those in arts and entertainment are independent contractors (or, as they are sometimes called, 'iPros' [independent professionals]), though the proportion in the information and communication sector who are iPros is only about 12 per cent, that in administrative and support service activities is about 9 per cent and that in the education sector is 4 per cent. 
Whereas in 2004 there were about 6.2 million iPros, by 2013 the number had increased to 8.9 million, a 45 per cent jump. In fact, iPros are now the fastest-growing type of worker in the EU, although there is significant geographical variation in this increase - their number grew 93 per cent in the Netherlands, 88 per cent in Poland and 85 per cent in France but only 43 per cent in Germany and 12 per cent in Italy. Moreover, whilst the proportion of the labour force employed in professional sectors grew by 5 per cent between 2008 and 2012, the number of iPro workers in these sectors grew by 16 per cent (Leighton 2013).

In Japan, by way of contrast, the phenomenon of independent contracting is relatively uncommon, though it has been growing in recent years. Hence, whereas in 2000 only about 633000 Japanese were independent contractors, by 2005 the number had grown by 80 per cent to 1.14 million people (which was still only 1.8 per cent of the overall labour force). Many, however, have become independent contractors involuntarily - a 2004 survey of such workers showed that only about 30 per cent said they preferred to work as independent contractors because it gave them 'job freedom' (Zhou 2011, p. 104). Similarly, in Australia a relatively small proportion of the labour force $(8.5$ per cent, some 986400 workers) were independent contractors in November 2013, with the highest proportion of them working in the construction industry (31 per cent), followed by the professional, scientific and technical services industry (15 per cent), whilst only about 8.8 per cent of workers were self-employed business operators (Australian Bureau of Statistics 2014, pp. 3, 8). Significantly, both of these categories of employment have declined in prevalence since the onset of the Global Financial Crisis - the former from 9.1 per cent of the labour force in 2008 and the latter from 10 per cent in 2008 - whilst the proportion of the Australian labour force who are permanent employees (defined as employees with paid leave entitlements, regardless of the number of hours they work) has actually been increasing in recent years - from 60.8 per cent in 1998 and 59.6 per cent in 2004 to 63.3 per cent in November 2013 (Australian Industry Group 2014). Older workers and men are more likely to be independent contractors or business owners than are younger workers or women (see Australian Bureau of Statistics 2014, p. 5). A similar situation with regard to older workers can be seen in South Korea - whereas some 30 per cent of the labour force is self-employed (a category that would include independent contractors), more than 80 per cent of these are employed in local services and a large number are older workers who start businesses after they retire (McKinsey \& Company 2013, p. 33). ${ }^{12}$ In China, although 'independent contractor' is not a recognized category under employment law, civil law does recognize that some workers can 
labour as individual service providers, though only in a small number of occupations (including cleaners, temporary helpers and drivers with their own vehicles for hire) and under strict conditions (e.g. they work no more than a few hours a week, they have no regular work schedule, they are not managed directly by someone else and they are compensated in lump sums rather than on a regular pay cycle) (Lin 2012).

In the US, on the other hand, whereas part-time work is the most common form of work that is often identified as contingent/precarious, 'independent contracting' has historically been the second most common. Hence, in the mid-1990s those determined by the federal government to be independent contractors accounted for 6.7 per cent of all workers and 21 per cent of the 39.6 million workers (one in three) in non-standard arrangements (US Government Accountability Office 2006a, p. 11). In 2005, according to the US Bureau of Labor Statistics (2006), 7.4 per cent of the overall 139 million strong labour force (some 10.3 million workers) were working as independent contractors. Unfortunately, these data on independent contractors were based upon the Contingent Work Supplement, a federal government survey that was discontinued in 2005. However, one recent unofficial count estimated that there were about 17.7 million independent contractors in the US in 2013, representing 8 per cent of the labour force, that by 2018 the number would be some 24 million, and that in 2020 about half of all private sector workers will have spent some of their lives as independent contractors (MBO Partners 2013, p. 3). ${ }^{13}$ Meanwhile, Intuit, a company that offers online services to small businesses, in 2010 suggested that by 2020 independent workers would make up 40 per cent of the US labour force (quoted in Dullroy and Cashman 2013, p. 25). Interestingly, one development which might facilitate the growth of all forms of contingent work, including independent contracting, has been the passage of the Affordable Care Act (aka Obamacare) because for millions of Americans it delinks access to health insurance from employment. Hence, as one report has put it, 'The new demand for contingent workers, the economic recovery and the passage of national healthcare will serve as the perfect trifecta to catapult contingent work arrangements to previously unachievable levels' (Littler Mendelson 2010, p. 36).

As with other types of contingent work, though, one of the key issues in trying to determine the number of independent contractors in different countries is that the definition of independent contracting is highly dependent upon a nation's legal code, which obviously can vary significantly (for details on national differences, see L\&E Global 2014). Moreover, given its basis in the realm of jurisprudence, the definition of what constitutes an independent contractor can change over time, making 
historical comparisons of the numbers of such workers difficult, even within the same country (for the US case, see Muhl 2002). Finally, definitions of different types of contingent work can vary even amongst different entities of the same government - Chatani (2008, pp. 3-4) notes, for instance, that in Japan the Ministry of Health, Labour and Welfare counted 12.9 million part-time workers in 2007 whilst the Statistics Bureau placed the number at 11.6 million. It is highly likely that the same kind of discrepancies could be found in other countries' official statistics.

In sum, whilst recognizing that we could have looked at different data and that the data given above may have some deficiencies (e.g. that the same agencies may count different types of work and workers in different ways), we nevertheless believe that the figures presented serve to give a sense of how labour markets have been changing in various parts of the world in recent decades, especially those which have some of the largest economies and which have historically been used to a more Fordist model of standard employment. Although there are variations, in many parts of the world there is little doubt that the connection with the labour market for millions of workers appears to have become much looser. We now turn to look at some of the reasons for this.

\section{PRESSURES ENCOURAGING THE GROWTH OF PRECARIOUS WORK}

Having detailed some historical and geographical trends concerning contingent/precarious work, in this section we outline some pressures that can lead to its spread. Certainly, there are good reasons why many workers might voluntarily engage in contingent work. For instance, they may want to only work part time because they are now securing incomes in ways that were less common and/or not open to them in the past (e.g. working-class people who may make substantial sums through fortuitous investing in the stock market via various online media) or because they wish to spend more time with family and do not desire to maximize earnings (i.e. they are willing to trade more free time for lower incomes). Some might prefer part-time or temporary work because they have increasingly adopted a mindset that challenges what Gorz (1999) has called the 'ideology of work', which for much of the history of capitalism has encouraged people to think that if they are not working they are somehow social failures. In other cases, workers may seek out part-time or fixed-term work simply to keep busy during retirement and to ensure that they have a degree of social interaction with people outside 
their homes. However, here we want to focus more particularly upon structural changes in how contemporary capitalism is operating and how this is encouraging more firms to look to contingent workers as a mainstay of their labour forces and to force contingent work on people involuntarily. Interestingly, though, in so doing it is important to recognize that there is often quite a dynamic and complex relationship between contingent and non-contingent, or precarious and non-precarious, work. Thus, on the one hand, the trend towards hiring temporary and part-time workers seems to be greater in those countries where regular employees have strong job protections than in those in which they do not, no doubt because employers are tempted to hire more non-regular workers whose employment can be more easily terminated when the employer feels the need to reduce the size of its labour force. Hence, in the 1980s and 1990s, countries with strong employment protections (like Spain, France and Italy) saw quite significant increases in the numbers of temporary jobs in their economies, whereas countries that had relatively weak protections (like the US and UK) did not (Booth et al. 2002). On the other hand, though, as Booth et al. (2002) indicated in their analysis of the UK, fixed-term contracts can sometimes be a stepping stone to more permanent work, especially for women. Equally, whereas in countries like the UK it has been typical for most workers to work in the formal economy, in many Global South countries, where the bulk of the labour force toils in the informal economy, gaining entrée to the formal economy through temporary or part-time positions has often been seen as a way to secure greater job security. However, even here in recent years the types of jobs being created are often precarious. Hence, in the case of China, whilst employment in the private, formal sector of the economy has been growing significantly in the past two or three decades, pulling millions of peasants out of the informal, rural economy, virtually all jobs created since the mid-1980s have adopted fixed-term contracts (ILO 2012, pp. 33-34).

In turning to examining those pressures that can encourage the spread of involuntary contingent/precarious work, however, it is important to bear several things in mind. The first is that, although in the industrialized Global North there has been much concern in the past few years (e.g. Hardt and Negri 2004) that precarious work's rise marks the dismantling of the Fordist model of employment, in which workers enjoyed good wages and working conditions guaranteed by the state, and the re-emergence and dominance of what Moody (1997, p. 97) calls 'archaic forms of labor organization', like contracting, casualization and homework, in actual fact the phenomenon of precarious work was quite common during this imagined 'golden age' of worker security. Thus, one 
need only watch the 1954 film On the Waterfront, with its shape-up of dockers on the piers of Hoboken, New Jersey, or delve into the history of union efforts in the 1970s to eliminate 'the lump' in the British building trades or efforts by the French anarcho-syndicalist Confédération générale du travail in the twentieth century to pressure cities to establish 'bourses du travail' (hiring halls) as a way to regularize work and hiring practices to see that the rise of Fordism did not eliminate many of the practices which had characterized the Dickensian working conditions of nineteenth-century industrial capitalism. ${ }^{14}$ Rather than being historically diachronic, with Fordism seen as having come after and having banished the precarity that typified nineteenth-century labour relations, Fordism and precarity were, in fact, synchronous - there are myriad examples of precarity operating within the period of the so-called Fordist mode of economic regulation. However, whereas much of the precarious labour which typified many nineteenth-century labour relations was employed by the small-scale firms which Adam Smith imagined to be the bedrock of the economy (and which neoliberals often laud as the imagined ultimate economic actors that ensure competitive capitalism), in the twentieth and early twenty-first centuries it has often been large, transnational corporations which have encouraged the spread of precarity. For instance, in the United States the growth of temp agencies can be traced to the period just after the Second World War, when several companies were started (Hatton 2011). Perhaps not coincidentally, these were largely based in the Midwest, which at the time was a bastion of union strength. Hence, in 1946 William Kelly founded Russell Kelly Office Service (later known as Kelly Girl Services) in Detroit, with a mere three employees, a dozen customers and $\$ 848$ in sales. The following year two lawyers, Aaron Scheinfeld and Elmer Winter, founded the equally small Manpower Inc. in Milwaukee. ${ }^{15}$ Largely cast at the time as 'women's work' - a rhetorical strategy which exploited cultural ambivalence about employing white, middle-class (and, often, married) women outside the home to create a class of workers who were effectively beyond the reach of a range of worker protections and who could be paid low wages because they were seen to be working for 'pin money' to supplement their husbands' incomes - temping was initially largely a phenomenon of the office sector and temps were hired for perhaps a day or two to fill in for workers who were sick or on vacation. Since then, however, it has spread dramatically - by 1967, for instance, Manpower employed more workers than did corporate giants like Standard Oil of New Jersey and US Steel (Hatton 2011). It has also changed significantly in nature - by 2013, 42 per cent of those working for temp agencies in the US were manufacturing or transportation workers, whilst only 21 per cent worked 
in office and administrative jobs (Smith and McKenna 2014, p. 1). Indeed, whereas the US automobile industry provided one of the main fountainheads out of which developed the strong unions that would supply much of the backbone to the US labour movement in the twentieth century, it is now quite common to see temps manufacturing parts for firms like Nissan and BMW alongside permanent workers (with these latter usually earning much more for doing the same kind of work).

Numerous studies have detailed why employers frequently turn to contingent workers. Houseman (2001), for instance, using a nationally representative survey of US private sector establishments, noted that employers use contingent workers for reasons as varied as the need for flexible staffing arrangements so that they might adjust for workload fluctuations and staff absences, as a mechanism to screen workers for regular positions which they may later be offered, and to save on benefits costs (in the US and many other countries, employers do not have to pay for various social welfare schemes - including health benefits, the costs of which continue to rise dramatically - for workers who are temporary or part-time employees). Sometimes, she found, managers may also turn to using temporary workers as a way to bypass headcount limits imposed by their corporate headquarters during restructuring or a merger. Baldoz et al. (2001) have suggested that hiring contingent workers can help relieve wage pressures on firms coming from their more permanent workers. For their part, Luo et al. (2010) have suggested that employers have increasingly turned to contingent workers since the 1990s to gain access - though often for short periods of time - to employees with highly specialized knowledge in particular processes or sets of operations, to quickly and efficiently address changing labour requirements caused by rapid changes in the market, because the growth of just-in-time manufacturing and inventory control systems have led to altered hiring patterns and the necessity to be able to hire and fire quickly, and because of the growth of niche labour-supply firms which, thanks to technology, can more easily supply firms' often-changing labour needs at fairly short notice (unlike in the past, when firms had to 'hoard' such workers so as to have them on hand when they needed them, even though at many other times they might not have work for them). This has all been facilitated by the growing partnerships developed between niche temp agencies and larger staffing firms. Significantly in all of this, whereas initially temp workers were fairly low-skilled so that they could easily be slotted into wherever they were needed - this week at an office filing papers, next week at a janitorial firm mopping floors - more recently workers with higher skill levels have started making up a larger proportion of employment in temporary help services and the demand coming from employers 
for workers with higher skill levels has increased. Thus, some of the fastest-growing temping activities are those in the legal field, in business and financial operations, in computer and mathematical fields, in education, and in community and social services work.

Thinking more broadly, though, a significant impetus towards the growth of contingent work - work which can readily become very precarious - has been the continued transformation of the spatiality of capitalism as a result of what Harvey (1989) has called 'time-space compression'. What Harvey means by this is that the growth of telecommunications and transportations technologies in the past few decades has led to both the shrinking of the relative distances between places - a phenomenon that Cairncross (2001) has termed the 'death of distance' and the 'acceleration of just about everything' (Gleick 1999), developments that Agger (1989) views as marking the emergence of an era of 'fast capitalism'. The result has been the emergence of what Foucault (1986) presciently called an 'epoch of simultaneity' in which our knowledge of actions - and thus our need to respond to them - has become virtually simultaneous with their occurrence, such that the time which economic actors have to respond to market changes has diminished significantly. Thus, when stock markets in New York react within minutes to events taking place in Asia, the need for firms to be sufficiently nimble that they might respond has encouraged them to seek both numerical and functional flexibility. The first of these - 'numerical flexibility' - typically involves firms ensuring that they have adequate labour on hand for when demand for their product increases but also that they can readily reduce their commitment to that labour when the opposite occurs. This can be done either within house by, for instance, judicious use of overtime, flexible work hours and/or reducing work to a part-time level, or by turning to the external labour market through, amongst other things, hiring more workers on fixed-term contracts, subcontracting out work and/or dismissing workers. Whereas the former method allows a firm to get more work out of its current employees when required but also to cut back on workers' hours when needed, the latter allows them to make use of pools of easily hired and fired workers. This model is often referred to as the 'American Model' of flexibility (Arvanitis 2005).

The second way of achieving flexibility - 'functional flexibility' involves having workers develop multiple competencies so that they may be readily switched between jobs as the need arises, through mechanisms like multi-tasking and job rotation. This model is often referred to as the 'European Model' of flexibility and assumes that workers have broadly based vocational qualifications so that they are well suited to undertaking new tasks within the firm. This frequently involves implementing new 
forms of workplace organization, such as job rotation and 'teamwork', forms of organization that usually involve reducing the number of work rules and job classifications and the protections that they may have provided workers over generations (MacDuffie 1995). Hence, whereas under the Fordist model wages were tied to particular jobs rather than to worker characteristics, such that all workers doing a specific job could usually expect to be paid the same, regardless of their individual performance of that job, and workers could expect some degree of employment security through 'owning' particular jobs as a result of their seniority, new models of 'lean employment' typically disconnect wages from specific jobs. This incites workers to compete with one another on the basis of performance for whatever wage increases may be available (thereby encouraging individualism in the workplace and discouraging the formation of class solidarities), dramatically reduces the number of job classifications in a workplace (such that workers' jobs are no longer fixed but are likely to change as production demands change), and means that the movement of workers from job to job is no longer determined on the basis of seniority rights. All of these changes challenge how labour unions have traditionally exercised power in the workplace through controlling particular jobs via the wage and seniority rules they had secured. As the geography of global capitalism seems to change ever more quickly thanks to the shrinking of distance between places and the speeding up of social life, then, the 'need' for capital to be flexible enough to respond instantly to market fluctuations from half a world away means that workers' abilities to make long-term plans are reduced and the precarity of their lives is increased.

In considering the tendency towards greater precarity, though, it is also important to contemplate the role of the state. This is because many of the developments which have been necessary for precarity to spread such as the signing of free trade agreements, the 'deregulation' of labour and financial markets and the privatization of previously public institutions - have required state actions. ${ }^{16}$ Thus, in much of both the 'socialist' and the capitalist world formerly state-owned firms have been sold off and their employees increasingly subjected to the vagaries of the market, many of the welfare state functions that were established during the twentieth century are being or have been dismantled, and numerous governments across the globe have subcontracted to private providers work they themselves previously did (such as processing food stamp claims) (US Government Accountability Office 2006b). However, the fact that neoliberal policies affecting workers and labour markets must be enacted by the state means that states can reverse these policies and, indeed, some have done so. Hence, whereas several Latin American 
countries' efforts to deregulate labour markets in the 1990s exposed the most vulnerable groups to worse wage and working conditions, thereby deepening inequalities and encouraging the spread of contingent work, in the early 2000s many of these initiatives were discarded, such that Latin America is the only region in the Global South where the informal economy is now beginning to decline, notably in Brazil (Fagan et al. 2014, p. 16). Likewise, after some public backlash several US states passed legislation forbidding the outsourcing of their own operations overseas, choosing to bring those jobs back to the United States, even though doing so would cost taxpayers more.

\section{IMPLICATIONS FOR THE FUTURE}

For many neoliberals, the move towards flexibility for capital is seen to reach its apogee in the development of so-called 'zero-hour contracts' in which workers are "not guaranteed any work but ha[ve] to be available as and when the employer needs them' (Bibby 1997). To make matters worse, in some instances workers subjected to such contracts have been forced to sign exclusivity agreements in which they consent not to look for work with other employers so that they are always potentially on hand for when their main employer might need them. In the UK, several well-known employers have made widespread use of zero-hour contracts, including McDonald's, the supermarket chain Tesco, the pharmacy chain Boots, Hertz Car Rental, Burger King and even Buckingham Palace. Indeed, according to the Workplace Employment Relations Survey conducted by the UK government (UK Department for Business, Innovation and Skills 2013), in 2011 about 8 per cent of all workplaces used zero-hour contracts, though this number jumped to 23 per cent of those with over 100 employees and 50 per cent of those with at least 250 employees. ${ }^{17}$ The government's Labour Force Survey indicated that between October and December 2014 there were some 697000 workers employed on zero-hour contracts (about 2.3 per cent of the labour force), whilst there were about 1.8 million zero-hour contract jobs worked, together with an additional 1.4 million such contracts under which no work was done during that time (UK Office of National Statistics 2015). ${ }^{18}$ In New Zealand, several companies owned by Restaurant Brands (including most of the country's Burger King, McDonald's, KFC, Starbucks and Pizza Hut franchises), together with Hoyts (operator of cinemas in Australia and New Zealand) and Skycity Entertainment Group (operator of casinos in Australasia), have also used zero-hour contracts, though in early 2015 Restaurant Brands agreed to stop doing so. 
Significantly, zero-hour contracts and other efforts to remove worker protections so as to encourage flexibility (like abolishing minimum wages, which are seen by some as artificially placing a floor on the 'true' rate at which workers might 'voluntarily' sell their labour) are often justified with arguments that draw upon Adam Smith to contend that both employer and employee are free to come to the marketplace to negotiate a price for which they will buy and sell labour - both parties, it is asserted, have the freedom to walk away from a bad deal. ${ }^{19}$ However, there are two issues to take into consideration here. First, the kind of economy about which Smith was writing, one in which small family firms dominated within a system of fairly competitive capitalism, is quite different from the kind of economy we have today - individual workers negotiating with a family-owned textile mill is very different from their negotiating with a transnational corporation. Second, this neoliberal vision of capitalism is but one vision. Thus, there are other views which, whilst not challenging capitalism per se, nevertheless argue for a different model of it - neo-Keynesians, for instance, maintain that workers need to be paid sufficiently for them to be able to consume the goods which the system produces, lest it collapse under the weight of its own lack of consumption. Put another way, it is important to recognize that the model of capitalism being pushed by many is but one paradigm, even amongst capitalists and their supporters in government. Recognizing that even amongst capitalists there are conflicts as to how they think the future should unfold, however, opens the door to contemplating how that future might be contested rather than imagined as being rolled out in some neoliberal teleology in which capital pushes the logic of accumulation to its ultimate and inevitable extreme - the infinitely flexible worker. This is particularly so given the divergence of opinion as to what is actually happening in the contemporary period. Hence, although many have argued that the trend towards contingent work is here to stay, others (e.g. Valletta and Bengali 2013) have suggested that, at least in the US, some kinds of contingent work (they focus specifically on part-time work) do not appear to be any more prevalent than they were in the early 1980s, once changes in survey measurement are taken into account. Whilst they do note that levels seem to be higher for certain types of workers (those who are younger and with less education), they also contend that 'the continued high incidence of part-time work likely reflects a slow labor market recovery [after the 2008 financial crisis] and does not portend permanent changes in the proportion of part-time jobs'.

Thinking about how the future is constructed through political struggle, rather than being something that is imagined to simply unfold according to the logic of capital accumulation, allows us to examine how workers 
are shaping the ways in which the world's labour markets are developing. Hence, instead of seeing labour markets as being constructed solely by the actions of capital in the way in which much neoliberal analysis does, here we point to some instances of workers shaping how such labour markets are unfolding. In this regard, we seek to connect challenges to precarity to the broader labour geography (Herod 2001) literature which explores how, adapting Marx's famous aphorism, workers make their own geographies but not under the conditions of their own choosing. For instance, the European Trades Union Council has negotiated framework agreements covering part-time and fixed-term employees. Equally, after pressure from the trade unions the European Union's Court of Justice, in its March 2015 ruling on Directive 2008/104/EC on temporary agency work, guaranteed the right of the various social partners (i.e. unions and employers) to regulate the use of temporary agency work in collective agreements. Likewise, in Washington, DC, taxi drivers, who are independent contractors, have turned to the Teamsters union as a way to protect their interests (Clark 2013). Meanwhile, in Japan unions have been engaged in seeking to organize part-time workers (Oh 2012). In other instances, workers have turned to corporate codes of labour practice, which, though they have limitations, can nonetheless be effective in certain circumstances (Barrientos 2008) because they represent companies' public statements of intent, and their failure to live up to these can provide something around which workers and their supporters can rally so as to bring pressure to bear on employers. There are myriad other examples of workers seeking to confront the growth of precarious work (some of which are recounted in this book). Certainly, organizing precarious workers presents challenges that organizing other workers does not. Precarious workers, for instance, are often hidden in the shadows of the economy. Equally, the growth of outsourcing has made it more difficult to trace lines of command and control and who has ultimate decision-making authority for the conditions under which workers labour, an opacity of responsibility that frequently makes it challenging for workers to exert their legal rights and for them to organize to pressure the appropriate entities when seeking to improve their lot. Nevertheless, the many examples of such workers developing organizations to further their goals indicates that there is nothing inevitable about the future. Certainly, precarious workers are in difficult situations. However, we - and they - should not succumb to the neoliberal fallacy that there is no alternative but to accept their condition. 


\section{FINAL THOUGHTS}

The growth, as part of the emergence of what is imagined to be a post-Fordist, neoliberal world, of a looser connection to the labour market for many workers and the dismantling of many of the protections for workers in the labour market is bringing with it many comparisons to the kind of capitalism that existed in the nineteenth century, when there was often little protection offered to workers. Indeed, former US Secretary of Labor Robert Reich (2015) has explicitly made the case that we are seeing a move 'back to the nineteenth century' and the re-emergence of a piece-work economy. Thus, it was only with the reforms of the Progressive Era in North America and Western Europe that meaningful limits began to be placed upon the power of capital to control labour markets. ${ }^{20}$ However, the social contract built up during the last quarter of the nineteenth century and into the first three-quarters of the twentieth, at least in many Global North countries, appears to be being replaced by the logic of the market whilst, of course, in many parts of the Global South no such social contract has ever existed. The logic of capital under neoliberalism, then, continues to radically revise labour market structures and operations as new (or reintroduced) forms of work are implemented and the state and capital reconfigure labour markets for the purposes of facilitating capital accumulation and the disciplining of workers. This raises questions about how different forms of precarious work are linked to specific institutional changes in the labour market and laws governing it but also how they are linked to each other. What, for instance, may lead some firms within a particular global production network to contract long term with industrial homeworkers to manufacture components but others to turn to day labourers or part-time or temporary workers to do so, even within quite 'modern' industrial sectors like that of electronics? Equally, what may lead a firm to outsource work to homeworkers at one time but to keep it inhouse and to use part-time workers at another?

The rise of precarious work also raises fundamental questions about the nature of capitalism as a system and its ability to reproduce itself. Thus, there is a clear tension between individual employers' desires often to pay as little as possible to facilitate accumulation and the collective need for consumption for the realization of profit. This is not to argue for a teleological view of capitalism, in which the rise of low-waged precarious work is seen somehow to augur the end of the system itself. But it is to suggest that there are deep systemic contradictions at play, a fact that raises questions about who will bear the consequences of any devaluation of capital and of labour caused by the overproduction of 
goods and services that cannot ever be consumed because there may not be sufficient collective purchasing power for their producers to realize a profit. This also has implications for how the state operates. Hence, the rise of zero-hour contracts is as much to do with employers avoiding paying taxes and other contributions that governments use for revenue as it is about employer flexibility. When combined with a model of governance that pushes low tax rates as a way for national or state and local economies to remain 'competitive' in an environment in which globally organized capital can play communities or countries against each other for tax breaks and subsidies (on this point, see Goodman 1979), the growth of low-wage work can have significant implications for a state's fiscal bottom line, especially if such low wages put strains on the state to make up the difference through various government transfers like food stamps, income supports and the provision of housing subsidies. Hence, in the UK the Trades Union Congress (2015) has recently estimated that lack of earnings growth (much of which can be attributed to low wages) means that the government is collecting some $£ 33.4$ billion less in income tax and national insurance payments than official forecasts had suggested would be the case. Such a lack of revenue is likely to lead to further calls for reductions in government services to ensure that deficits do not get 'out of hand' and may result in what TUC General Secretary Frances O'Grady (2015) suggests will be a 'shrinking [of] the state to a level not seen since the 1930 s - before we had the ... welfare state safety net'.

In thinking about how neoliberal capitalism is shaping labour markets and workers' life chances it is also important, though, to consider how workers' precarity in the labour market can shape their biological precarity. As Engels ([1844] 1993, pp. 252-253) observed a century and a half ago, the type of work that people do can dramatically shape how their bodies develop and function, an observation also supported by more recent analysts (see Komlos 1990; Søgaard et al. 2006; and Chapters 6 and 7 in this volume). The failure of workers to secure work of sufficient quantity and quality for them to be able to reproduce themselves biologically on a daily and generational basis, then, can have significant consequences for them. But more than there just being a connection between precarity and how individual workers' bodies function, given that how capitalism functions shapes how Nature is produced (Smith 1984), we must also consider that there is a connection between the kind of political economic system which produces precarity in the workplace and one that produces precarity in the environment more broadly. This is because the production of Nature and the production of the geography of capitalism are intimately intertwined. Hence, one important factor in 
bringing about the precarity experienced by millions of workers has been seeing their jobs outsourced by globally organized capital to the poorestpaid workers in various regions of the world. Such outsourcing has been facilitated by the availability of cheap oil (and thus historically low transportation costs), the use of which has contributed to the proliferation of the greenhouse gases that are causing the ever more frequent extreme weather events which are making many people's lives much more precarious - the rise in sea-levels just in the Indian Ocean brought about by human-induced climate change, for instance, threatens millions with harsher monsoonal flooding, which is likely to place crops, homes and livelihoods at risk and lead many to become 'climate refugees'. Significantly, though, this connection between precarity in the workplace and ecological precarity is being recognized by some labour groups, who see both types of precarity as emerging out of the transformations being wrought by neoliberalism (see Hampton 2015 for an analysis of the UK union movement's engagement with climate change).

Finally, we must also think about the link between the politics of the production of precarity and the politics of knowledge production, in at least two ways. First, what is considered to be precarious work, as hinted at above, varies by culture and location. There is, in other words, a distinct geography to workers' and others' consciousness of precarity, a geography which will shape how economies in particular places are understood. This recognition connects studies of precarity into the broader realm of analyses of how economies are constructed discursively (see Mitchell 1998 and Thrift 2000 for more on this). Second, how workers understand their own precarity will be shaped by their own histories in the labour market. Thus, if they previously enjoyed 'regular' employment but are now forced to work in precarious positions they may very well understand the nature of contemporary neoliberal capitalism in markedly different ways than do workers who have never known anything but precarity. This will undoubtedly shape their politics. Although, then, precarity seems to be a concern of many workers and academics in the Global North, in many ways it does not represent that much of a difference for many millions of workers across the planet. We should be careful, in other words, not to universalize the experience of those workers who previously enjoyed secure and well-remunerated work within a Fordist economy, as there are many who have never had such luxuries. 


\section{NOTES}

1. Although there are many definitions of 'neoliberalism', in general the term refers to a type of regulation of the economy in which the state as a guarantor of residents' social welfare is withdrawn, in which demand-side macro-economic policies are replaced by supply-side ones and in which the market is seen to be the ultimate way through which to allocate social resources.

2. Justice Potter Stewart, concurring in Jacobellis v. Ohio, 378 US 184 (1964), emphasis added.

3. We prefer the term 'precarious work' to 'contingent work' or 'atypical work' because it carries with it, we feel, a greater sense of work as not being securely held and uncertainty for workers than do these other terms.

4. The year 2007 is chosen as the bookend in these data because it is the last full year before the Global Financial Crisis hit. During the crisis temporary workers were disproportionately affected by lay-offs, and so looking beyond that date would give an underestimation of precarious work's spread (ILO 2012, p. 31).

5. The low numbers of workers dispatched from temporary help agencies reflects the fact that such entities were illegal in Japan prior to 1985.

6. Although this represented a slight decrease from 2005, the 20 largest South Korean companies increased their employment of temporaries by 15.2 per cent between 2012 and 2013, with Kia Motors posting the country's largest increase (at 520 per cent) and Hyundai recording an 87.5 per cent increase (DCR Workforce 2014).

7. In 1963 women's median employment tenures were as follows: 7.8 years for women aged 55-64, 6.1 years for women aged 45-54, 3.6 years for women aged 35-44 and 2.0 for women aged 25-34. In 2012, the numbers were 10.0 years, 7.3 years, 5.2 years and 3.1 years (Copeland 2012, figure 3). Median tenure is also highly racialized, with a higher proportion of white workers having at least 10 years of tenure with their current employer than do black, Asian and Hispanic workers (Hipple and Sok 2013).

8. Much of this is a reflection of the generous state support provided for young mothers, which allows Dutch women to more easily work part time (McKinsey \& Company 2013, p. 71).

9. Until 1998 Korean labour law prohibited laying off workers. However, the law was changed in reaction to the 1997 financial crisis. In response, firms not only began to terminate workers but also increasingly to use other forms of 'flexible' employment (Kim and Park 2006, p. 441).

10. Although most of the figures on part-time work given here are for 2011, those for Brazil are for 2009 and for Trinidad and Tobago are for 2002.

11. The figures for Thailand are for 2000, for Trinidad and Tobago they are for 2002 and for Indonesia they are for 2003.

12. Obtaining data on the number of independent contractors in Korea is difficult. However, the OECD (2013, p. 110) indicates that in the first decade of the 2000s the proportion of the labour force employed 'atypically' fluctuated between about 20 and 25 per cent. This has been complicated by the fact that courts have been less reluctant recently to designate an independent contractor an 'employee' under the Labour Standards Act, even in cases where an employer establishes that the worker is aware that he/she was hired as an independent contractor (Hayes 2011).

13. In this study 'independent contractors' were those who 'self-identify as contractors, freelancers, consultants, temps, solopreneurs, microbusiness owners (with no more than 3 employees in this study), or those working on-call without schedule/income guarantees' for at least 15 hours per week (MBO Partners 2013, p. 5).

14. In 1966 the British government introduced the selective employment tax, which allowed employers to fire thousands of directly employed construction workers and then to immediately re-employ them as 'self-employed' contractors. This allowed employers to avoid paying directly to the government the income taxes and national insurance payments that they would normally have paid on these workers' behalf. Instead, the workers were 
paid a lump sum and expected to make their own contributions. Although this 'working on the lump' offered the potential for workers to earn higher take-home pay, it did so at the expense of their long-term security - many simply would pocket the money. Turning these workers into self-employed contractors also made it more difficult for the building trades unions to organize (Mordsley 1975).

15. In 2014 Kelly had revenue of US\$5.6 billion and provided work to more than 555000 temps. In 2010, the ManpowerGroup had sales of US\$19 billion and provided work to more than 4.4 million temps.

16. We have problematized the concept of 'deregulation' through the use of quotation marks because, following Vogel (1996), we see that much 'deregulation' (which might imply the removal of rules and regulations) is actually very much part of a 'reregulation' of the economy - i.e. it is not so much that rules and regulations are being removed but, instead, that how markets and economies are being regulated is changing.

17. This last figure is for August 2014 (UK Office of National Statistics 2015, p. 4).

18. The explanation for the greater number of contracts than people is that many workers worked multiple such contracts or used a zero-hour contract to do work supplementary to their regular job (i.e. 'worked on the side').

19. Marx ([1867] 1976), of course, famously critiqued such a view with his comments about the worker's so-called 'double freedom'.

20. One of these efforts involved limiting the 'freedom of contract', in which any agreement between employers and workers was assumed legitimate if both sides 'voluntarily' agreed to it. This allowed employers to force workers to toil under often-terrible conditions or else face legal sanctions for breach of the labour contracts into which they had 'voluntarily' entered (see Steinfield 2001).

\section{REFERENCES}

Agger, B. (1989), Fast Capitalism: A Critical Theory of Significance, Urbana: University of Illinois Press.

Arvanitis, S. (2005), 'Modes of labor flexibility at firm level: Are there any implications for performance and innovation? Evidence for the Swiss economy', Industrial and Corporate Change, 14 (6), 993-1016.

Asao, Y. (2011), 'Overview of non-regular employment in Japan', in Japan Institute for Labour Policy and Training (ed.), Non-regular Employment: Issues and Challenges Common to the Major Developed Countries, Tokyo: Japan Institute for Labour Policy and Training, pp. 1-42.

Australian Bureau of Statistics (2014), 'Forms of employment, Australia, November 2013', Australian Bureau of Statistics, Canberra.

Australian Industry Group (2014), 'Economics fact sheet: Forms of employment in Australia - Casual workforce is stable but self-employment has declined', 7 October.

Baldoz, R., C. Koeber and P. Kraft (2001), 'Making sense of work in the twenty-first century', in R. Baldoz, C. Koeber and P. Kraft (eds), The Critical Study of Work: Labor, Technology, and Global Production, Philadelphia, PA: Temple University Press, pp. 3-16.

Barrientos, S. (2008), "Contract labour: The "achilles heel" of corporate codes in commercial value chains', Development and Change, 39 (6), 977-990.

Bibby, A. (1997), 'Close to the core: Zero hours working surveyed', Flexible Working (magazine), January. 
Bloomberg.com (2014), 'Japanese job market shifts to part-time, lower pay', available at www.bloomberg.com/infographics/2014-05-30/japanese-jobmarket-shifts-to-part-time.html (accessed 23 July 2015).

Booth, A.L., M. Francesconi and J. Frank (2002), 'Temporary jobs: Stepping stones or dead ends?', Economic Journal, 112 (480), F189-F213.

Business Korea (2014), 'Increasing temporary workers: Number of temporary workers breaks 6 million mark', 29 October, available at www.business korea.co.kr/article/7020/increasing-temporary-workers-number-temporaryworkers-breaks-6-million-mark (accessed 23 July 2015).

Cairncross, F. (2001), The Death of Distance: How the Communications Revolution Is Changing Our Lives, Boston, MA: Harvard Business School Press.

Chatani, K. (2008), 'Non-regular employment and gaps in statistics in Japan', paper for the Women in Informal Employment: Globalizing and Organizing Conference on 'Measuring Informal Employment in Developed Countries', Harvard University, 31 October - 1 November.

Clark, P. (2013), 'More independent contractors are organizing: Meet Teamster taxi cabs', Bloomberg.com, 31 October, available at www.bloomberg.com/ bw/articles/2013-10-31/more-independent-contractors-are-organizing-dot-meetteamster-taxi-cabs (accessed 23 July 2015).

Copeland, C. (2012), 'Employee tenure trends, 1983-2012', Employee Benefit Research Institute Notes, 33 (12), 2-13.

Day, D. (1952), 'Poverty and precarity', Catholic Worker, May, available at www.catholicworker.org/dorothyday/articles/633.pdf (accessed 23 July 2015).

DCR Workforce (2014), 'Top South Korean companies turning to temp workers', 1 June, available at http://trendline.dcrworkforce.com/top-south-koreancompanies-turning-to-temp-workers.html (accessed 23 July 2015).

Dullroy, J. and A. Cashman (2013), Independents Unite! Inside the Freelancers' Rights Movement, Berlin, available at www.freelancersmovement.org (accessed 23 July 2015).

Economist (2015), 'Why so many Dutch people work part time', 11 May, available at www.economist.com/blogs/economist-explains/2015/05/economistexplains-12? fsrc=scn/fb/wl/ee/st/ed/whysomanydutchpeopleworkparttime (accessed 23 July 2015).

Elliott, L. (2013), 'Zero-hours contract workers - The new reserve army of labour?', Guardian Weekly, 4 August, available at www.theguardian.com/uknews/economics-blog/2013/aug/04/zero-hours-contract-workers-reserve-armylabour (accessed 23 July 2015).

Engels, F. ([1844] 1993), The Condition of the Working Class in England, Oxford: Oxford University Press.

Eurostat (2015), 'Part-time employment rate', available at http://ec.europa. $\mathrm{eu} /$ eurostat $/ \mathrm{tgm} / \mathrm{table} . \mathrm{do} ? \mathrm{tab}=$ table $\&$ init $=1 \&$ plugin $=1 \&$ pcode $=$ tesem $100 \&$ language=en (accessed 23 July 2015).

Fagan, C., H. Norman, M. Smith and M.C. González Menéndez (2014), In Search of Good Quality Part-time Employment, Conditions of Work and Employment Series No. 43, Geneva: International Labour Office.

Florida, R. (2002), The Rise of the Creative Class: And How It's Transforming Work, Leisure, Community and Everyday Life, New York: Basic Books. 
Foucault, M. (1986), 'Of other spaces', Diacritics, 16 (1), 22-27.

Freedman, A. (1988), Testimony of Audrey Freedman before the Employment and Housing Subcommittee of the Committee on Government Operations, House of Representatives, 100th Congress of the United States, 19 May.

Gleick, J. (1999), Faster: The Acceleration of Just about Everything, New York: Pantheon.

Goodman, R. (1979), The Last Entrepreneurs: America's Regional War for Jobs and Dollars, New York: Simon \& Schuster.

Gorz, A. (1999), Reclaiming Work: Beyond the Wage-based Society, Cambridge: Polity.

Hampton, P. (2015), Workers and Trade Unions for Climate Solidarity: Tackling Climate Change in a Neoliberal World, Abingdon: Routledge.

Hardt, M. and A. Negri (2004), Multitude: War and Democracy in the Age of Empire, New York: Penguin.

Harvey, D. (1989), The Condition of Postmodernity: An Enquiry into the Origins of Cultural Change, Oxford: Blackwell.

Hatton, E. (2011), The Temp Economy: From Kelly Girls to Permatemps in Postwar America, Philadelphia, PA: Temple University Press.

Hayes, S. (2011), 'Korean independent contractor risks under LSA', available at www.thekoreanlawblog.com/2011/07/korean-independent-contractor-risks.html (accessed 23 July 2015).

Herod, A. (2001), Labor Geographies: Workers and the Landscapes of Capitalism, New York: Guilford.

Hipple, S. and E. Sok (2013), 'Tenure of American workers', Bureau of Labor Statistics Spotlight on Statistics, September, available at www.bls.gov/ spotlight/2013/tenure (accessed 23 July 2015).

Houseman, S. (2001), 'Why employers use flexible staffing arrangements: Evidence from an establishment survey', Industrial and Labor Relations Review, 55 (1), 149-170.

Houseman, S. and M. Osawa (1995), 'Part-time and temporary employment in Japan', Monthly Labor Review, October, pp. 10-18.

Houseman, S. and A. Polivka (1998), The Implications of Flexible Staffing Arrangements for Job Security, BLS Working Paper 317, Washington, DC: US Department of Labor, Office of Employment Research and Program Development.

ILO (International Labour Organization) (2012), From Precarious Work to Decent Work: Outcome Document to the Workers' Symposium on Policies and Regulations to Combat Precarious Employment, Geneva: ILO, Bureau for Workers' Activities.

ILO (International Labour Organization) (2015), World Employment and Social Outlook: The Changing Nature of Jobs, Geneva: ILO.

Kim, A.E. and I. Park (2006), 'Changing trends of work in South Korea: The rapid growth of underemployment and job insecurity', Asian Survey, 46 (3), 437-456.

Koide, K. (2014), 'Will Japan have sustainable wage increases? A key to overcoming deflation', DIAM Economic Research Note, DIAM Co., available at www.diam-international.com/sites/default/files/DIAM\%20Economic\%20 
Research\%20Note\%20by\%20Kozo\%20Koide\%20-\%20Sep\%202014.pdf (accessed 23 July 2015).

Komlos, J. (1990), 'Height and social status in eighteenth-century Germany', Journal of Interdisciplinary History, 20 (4), 607-621.

L\&E Global (2014), Employees vs Independent Contractors, Brussels: L\&E Global, available at http://knowledge.leglobal.org/wp-content/uploads/LEGlobal-Annual-Publication-2014.pdf (accessed 23 July 2015).

Law Commission of Ontario (2009), "II. What we mean by "precarious work" and "vulnerable workers", available at www.lco-cdo.org/en/vulnerableworkers-background-paper-sectionII (accessed 23 July 2015).

Leighton, P. (2013), Future Working: The Rise of Europe's Independent Professionals (iPros), report for the European Forum of Independent Professionals, available at www.efip.org/future-working-the-rise-of-europeans-independentprofessionals (accessed 23 July 2015).

Lin, C. (2012), 'Mainland China - Risks in de facto employment', part of an online webinar on 'Employment law challenges for multinational employers in Hong Kong, Mainland China, Japan and Australia - Session 3: Nonemployment staffing solutions' presented on 22 March for DLA Piper. Informational slides and webinar archive available at www.dlapipercentral cms.com/export/system/central-cms/shared-pdfs/2012/events/EPB_Session_ Three_Presentation.pdf (accessed 23 July 2015).

Littler Mendelson (2010), The Littler Ten: Employment, Labor and Benefit Law Trends for Navigating the New Decade, available at www.littler.com/ publication-press/publication/littler-ten-employment-labor-and-benefit-law-trendsnavigating-new-dec (accessed 23 July 2015).

Liu, C.Y. and R. Kolenda (2011), Flexible Work Arrangements in Georgia: Characteristics and Trends, Report No. 236, Atlanta: Georgia State University, Andrew Young School of Policy Studies, Fiscal Research Center.

Luo, T., A. Mann and R. Holden (2010), 'The expanding role of temporary help services from 1990 to 2008', Monthly Labor Review, August, pp. 3-16.

MacDuffie, J. (1995), 'Workers' roles in lean production: The implications for worker representation', in S. Babson (ed.), Lean Work: Empowerment and Exploitation in the Global Auto Industry, Detroit, MI: Wayne State University, pp. 54-69.

Marx, K. ([1867] 1976), Capital: A Critique of Political Economy, Vol. I, London: Penguin.

MBO Partners (2013), The State of Independence in America: Third Annual Independent Workforce Report, available at www.mbopartners.com/state-ofindependence (accessed 23 July 2015).

McKinsey \& Company (2013), 'Beyond Korean style: Shaping a new growth formula', McKinsey Global Institute, April, available at www.mckinsey.com/ insights/asia-pacific/beyond_korean_style (accessed 23 July 2015).

Mitchell, T. (1998), 'Fixing the economy', Cultural Studies, 12 (1), 82-101.

Moody, K. (1997), Workers in a Lean World: Unions in the International Economy, London: Verso.

Mordsley, B.I. (1975), 'Some problems of the lump', Modern Law Review, 38 (5), 504-517. 
Muhl, C. (2002), 'What is an employee? The answer depends on the federal law', Monthly Labor Review, January, pp. 3-11.

OECD (Organisation for Economic Co-operation and Development) (2012), OECD Employment Outlook 2012, Paris: OECD.

OECD (Organisation for Economic Co-operation and Development) (2013), Strengthening Social Cohesion in Korea, Paris: OECD.

OECD (Organisation for Economic Co-operation and Development) (2014), OECD Employment Outlook 2014, Paris: OECD.

O'Grady, F. (2015), Frances O'Grady, General Secretary of the UK Trades Union Congress, quoted in 'Wage stagnation has increased the deficit by at least $£ 33$ bn, says TUC', TUC press release, available at www.tuc.org.uk/economicissues/public-spending/economic-analysis/britain-needs-pay-rise/wage-stag nation-has (accessed 23 July 2015).

Oh, H.-S. (2012), 'The unionization of part-time workers in Japan', Journal of Industrial Relations, 54 (4), 510-524.

Polivka, A. (1996), 'Contingent and alternative work arrangements, defined', Monthly Labor Review, October, pp. 3-9.

Rapelli, S. (2012), European I-Pros: A Study, Report for the European Forum of Independent Professionals, available at www.ipse.co.uk/sites/default/files/ media/documents/RESOURCES/efip_report_english.pdf (accessed 23 July 2015).

Reich, R. (2015), 'Back to the nineteenth century', available at http:// robertreich.org/post/110555525570 (accessed 23 July 2015).

Republic of Korea (2014), 'Employment plan 2014', available at https://g20.org/ wp-content/uploads/2014/12/g20_employment_plan_korea-1.pdf (accessed 23 July 2015).

Sayer, A. (1984), Method in Social Science: A Realist Approach, London: Hutchinson.

Smith, N. (1984), Uneven Development: Nature, Capital and the Production of Space, Oxford: Basil Blackwell.

Smith, R. and C. McKenna (2014), Temped Out: How the Domestic Outsourcing of Blue-collar Jobs Harms America's Workers, National Employment Law Project and National Staffing Workers Alliance, available at www.nelp.org/ publication/temped-out-how-domestic-outsourcing-of-blue-collar-jobs-harmsamericas-workers (accessed 23 July 2015).

Søgaard, K., A. Blangsted, A. Herod and L. Finsen (2006), 'Work design and the labouring body: Examining the impacts of work organisation on Danish cleaners' health', Antipode, 38 (3), 579-602.

Staffing Industry Analysts (2014), 'US adds 10,100 temp jobs; penetration rate hits new high', Daily News, 3 July, available at www.staffingindustry.com/ Research-Publications / Daily-News /US-adds-10-100-temp-jobs-penetration-ratehits-new-high-30643 (accessed 23 July 2015).

Standing, G. (2011), The Precariat: The New Dangerous Class, London: Bloomsbury Academic.

Steinfield, R. (2001), Coercion, Contract, and Free Labor in the Nineteenth Century, Cambridge: Cambridge University Press. 
Thrift, N. (2000), 'Pandora's box? Cultural geographies of economies', in G. Clark, M. Feldmann and M. Gertler (eds), The Oxford Handbook of Economic Geography, Oxford: Oxford University Press, pp. 689-702.

Trades Union Congress (2015), 'The living standards tax gap just got bigger: Why falling wages and tax giveaways have hit revenues', report prepared for the TUC by the Institute for Public Policy Research, February.

UK Department for Business, Innovation and Skills (2013), The 2011 Workplace Employment Relations Study (WERS), London: UK Government.

UK Office of National Statistics (2015), Analysis of Employee Contracts That Do Not Guarantee a Minimum Number of Hours, 25 February, London: UK Government.

US Bureau of Labor Statistics (2005), 'Contingent and alternative employment arrangements, February 2005', available at www.bls.gov/news.release/pdf/ conemp.pdf (accessed 23 July 2015).

US Bureau of Labor Statistics (2006), 'Contingent and alternative work arrangements supplement to the Current Population Survey, February 2005', table 28, available at www.bls.gov/cps/wlf-table28-2006.pdf (accessed 23 July 2015).

US Bureau of Labor Statistics (2014), 'Employee tenure in 2014', 18 September, available at www.bls.gov/news.release/tenure.nr0.htm (accessed 23 July 2015).

US Bureau of Labor Statistics (2015a), 'Charting the labor market: Data from the Current Population Survey (CPS)', chart 7 (Part-time workers as a percent of total employed, seasonally adjusted, 1990-2015), available at www.bls.gov/ web/empsit/cps_charts.pdf (accessed 23 July 2015).

US Bureau of Labor Statistics (2015b), 'Labor force statistics from the Current Population Survey: (Seas) employed, usually work part time', available at http://data.bls.gov/timeseries/LNS12600000?series_id=LNS12000000 (accessed 23 July 2015).

US Bureau of Labor Statistics (2015c), 'Labor force statistics from the Current Population Survey: (Seas) employment level - Part-time for economic reasons, all industries', available at http://data.bls.gov/timeseries/LNS12032194 (accessed 23 July 2015).

US Government Accountability Office (2006a), 'Employment arrangements: Improved outreach could help ensure proper worker classification', Report GAO-06-656 to the Ranking Minority Member, Committee on Health, Education, Labor, and Pensions, US Senate, Washington, DC.

US Government Accountability Office (2006b), 'Offshoring in six human services programs', Report GAO-06-342 to Congressional Committees, Washington, DC.

US Government Accountability Office (2015), 'Contingent workforce: Size, characteristics, earnings, and benefits', Report GAO-15-168R to US Senators Murray and Gillibrand, Washington, DC.

Valletta, R. and L. Bengali (2013), 'What's behind the increase in part-time work?', Federal Reserve Bank of San Francisco Economic Letter, 26 August.

Vogel, S. (1996), Freer Markets, More Rules: Regulatory Reform in Advanced Industrial Countries, Ithaca, NY: Cornell University Press.

Wall Street Journal (2015), 'Japan has plenty of jobs, but workers still struggle', 12 March, available at www.wsj.com/articles/japan-has-plenty-of-jobs-butworkers-still-struggle-1426197511 (accessed 23 July 2015). 
Yamamoto, C. (2013), 'Increasing temporary employment in Japan: Polarisation in the labour market and the "working poor" - Part 1', Employment Law Worldview, 15 November, available at www.employmentlawworldview.com/ increasing-temporary-employment-in-japan (accessed 23 July 2015).

Zhou, Y. (2011), 'Working as an independent contractor in Japan and the U.S.: Is it a good option for married women with young children?', Japan Labor Review, 8 (1), 103-124.

Zhou, Y. (2013), 'The state of precarious work in China', American Behavioral Scientist, 57 (3), 354-372. 
Andrew Herod and Rob Lambert - 9781781954959 Downloaded from PubFactory at 04/26/2023 06:49:01AM via free access 